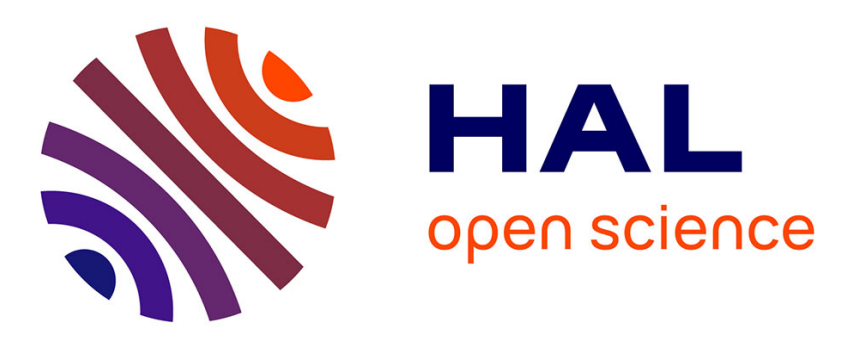

\title{
The inhibition of TOR in the model diatom Phaeodactylum tricornutum promotes a get-fat growth regime
}

\author{
Laura Prioretti, Luisana Avilan, Fredéric Carrière, Marie-Helene Montane, \\ Ben Field, Gérald Grégori, Benoît Menand, Brigitte Gontero
}

\section{To cite this version:}

Laura Prioretti, Luisana Avilan, Fredéric Carrière, Marie-Helene Montane, Ben Field, et al.. The inhibition of TOR in the model diatom Phaeodactylum tricornutum promotes a get-fat growth regime. Algal Research - Biomass, Biofuels and Bioproducts, 2017, 26, pp.265 - 274. 10.1016/j.algal.2017.08.009 . hal-01696878

\section{HAL Id: hal-01696878 https://hal.science/hal-01696878}

Submitted on 24 Apr 2018

HAL is a multi-disciplinary open access archive for the deposit and dissemination of scientific research documents, whether they are published or not. The documents may come from teaching and research institutions in France or abroad, or from public or private research centers.
L'archive ouverte pluridisciplinaire HAL, est destinée au dépôt et à la diffusion de documents scientifiques de niveau recherche, publiés ou non, émanant des établissements d'enseignement et de recherche français ou étrangers, des laboratoires publics ou privés. 


\title{
The inhibition of TOR in the model diatom Phaeodactylum
}

\section{tricornutum promotes a get-fat growth regime}

\author{
L.Priorettia, L.Avilan ${ }^{a}$, F.Carrière ${ }^{b}$, M-H.Montanéc ${ }^{2}$ B.Fieldc, G.Grégorid, \\ B.Menand ${ }^{c}$, B.Gontero ${ }^{\mathrm{a}}$
}

a - Aix Marseille Univ CNRS, BIP UMR 7281, 31 Chemin Joseph Aiguier, 13402 Marseille Cedex 20, France

b - Aix Marseille Univ, CNRS, EIPL UMR 7282, 31 Chemin Joseph Aiguier, 13402 Marseille Cedex 20, France

c - Aix Marseille Univ, CEA, CNRS, UMR7265 BVME, 13009 Marseille, France $d$ - Aix Marseille Univ, CNRS/INSU, Université de Toulon, IRD, Mediterranean Institute of Oceanography (MIO) UM110, 13288 Marseille, France

\begin{abstract}
The target of rapamycin (TOR) signaling pathway regulates fundamental intracellular functions critical for cell viability and proliferation. Manipulation of TOR in high lipidproducing microalgae may help overcome the trade-off between biomass production and lipid yield that still impairs the viable production of biofuel from microalgae. In this study, we inhibited the TOR kinase in the model diatom Phaeodactylum tricornutum using the selective TOR inhibitor AZD-8055, and analyzed cell proliferation, chlorophyll content, lipid synthesisand carbon metabolism. AZD-8055 inhibits cell proliferation in a dose-dependent manner compared to $\mathrm{N}$ deprivation which stops growth. Microscopy, flow cytometry, and quantitative analyses of lipids also demonstrated that AZD-8055 treatment strongly promotes triacylglycerol (TAG) accumulation while decreasing the quantity of sterols. The TAG productivity of AZD8055 treated cultures was significantly higher than for $\mathrm{N}$ deprived cultures. Measurement of the activities of the key metabolic enzymes glyceraldehyde phosphate dehydrogenase (GAPDH), glucose-6-phosphate dehydrogenase (G6PDH) and malate dehydrogenase (MDH) revealed opposite effects for AZD-8055 treatment and $\mathrm{N}$-starvation on the activity of the glycolytic enzyme GAPDH. This suggests that TOR inhibition and $\mathrm{N}$ starvation may have distinct impacts on general metabolism and lipid accumulation. Our main finding is that treating cultures with AZD-8055 results in higher TAG productivity than N starvation in $P$. tricornutum. The chemical or genetic manipulation of the TOR signaling pathway in $P$. tricornutum and other diatoms may lead to the development of strains or approaches suitable for the enhanced production of TAGs for biofuel.
\end{abstract}

Graphical abstract 


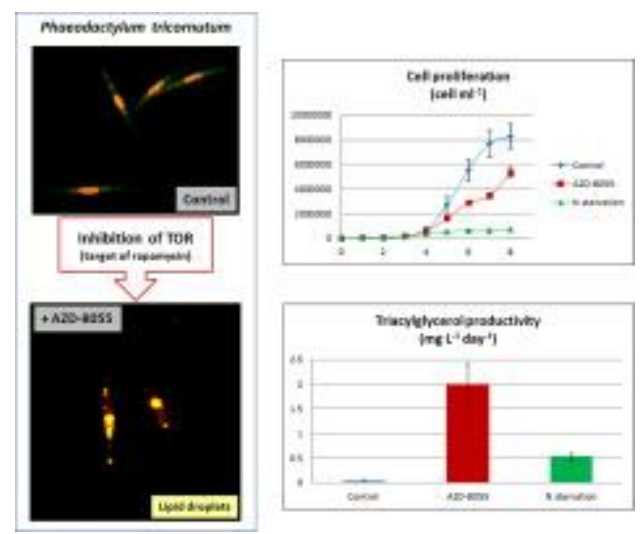

\section{Abbreviations}

AZ, TOR inhibitor AZD-8055,DAG diacylglycerol, FFA free fatty acids, G6PDH glucose-6-phosphate dehydrogenase, GAPDH glyceraldehyde phosphate dehydrogenase, GC-MS gas chromatography coupled to mass spectrometry, MAG monoacylglycerol, MDH malate dehydrogenase, TAG triacylglycerol,TLC-FID thin layer chromatography coupled to flame ionization detection, TOR target of rapamycin

\section{Keywords}

Microalgae, Target of rapamycin, Lipid metabolism, Biofuel, AZD-8055 ,Lipid productivity

\section{Introduction}

Since the second half of the XIX century the use of natural resources, like fossil fuels, gas and coal for sustaining human activities has been experiencing exponential growth. Although this historical phenomenon, known as the Industrial Revolution, had beneficial effects on human society, it has also led to long-term catastrophic effects on the environment with consequences for human health. Combustion of fossil fuels is indeed one of the main factors responsible for greenhouse gases emissions $\left(\mathrm{CO}_{2}\right)$ and atmospheric release of toxic compounds, which in turn are involved in global warming, ocean acidification and various types of diseases [1,2]. The search for sustainable and less polluting energy alternatives has now become a mission of paramount importance. Third-generation biofuels from microalgaereconcile the high demand for liquid fuels with many of the technical problems encountered in other oil-producing organisms like crops [3]. While unicellular photosynthetic organisms represent only about $0.2 \%$ of the global biomass, they account for almost $50 \%$ of the global net primary production [4] and the energy that they can store in the form of lipids represents $>20 \%$ 
of dry weight under nutrient-sufficient growth conditions [5]. This percentage can rise to $70-80 \%$ in some species of eukaryotic microalgae under nutrient limitation [3].

Diatoms (Bacillariophyceae) are the predominant class of eukaryotic microalgae in the oceans, where they account for about $40 \%$ of net primary production (the remainder accounted by other eukaryotic organisms and cyanobacteria; [6]), and possess qualities (high photosynthetic efficiency, fast growth and the capacity to store energy and carbon in the form of neutral lipids) that make them one of the most suitable groups for biofuel production [7,8]. The advanced genetic engineering tools developed in the diatom Phaeodactylum tricornutum, whose genome is known [9-13], make it one of the preferred model microalgae for biotechnology studies. In spite of this, biofuel production from microalgae is still a challenging process as the highest lipid accumulation per cell is achieved when the algae are subject to stress conditions like nitrogen starvation [14], which ultimately limits the overall biomass and thus lipid yield. The study and manipulation of signaling pathways regulating cell growth and metabolism, for instance, the target of rapamycin (TOR) pathway, may help to combine high lipid yields with the maintenance of cell proliferation. TOR manipulation for biofuel production was first proposed in a study showing that TOR repression in Arabidopsis thaliana artificial microRNA (amiR) lines affects carbon metabolism and results in starch and TAG accumulation associated with growth repression [15]. Further studies showed that TOR inhibitors could induce TAG accumulation in the red alga Cyanidioschyzon merolae and the green alga Chlamydomonas reinhardti[16,17]. However, TAGs were measured only at TOR inhibitor concentrations that stop proliferation and TAG productivity was not studied. A recent study on Euglena gracilis, a distant alga belonging to the Excavata, reported that the TOR inhibitor rapamycin has little effect on proliferation, yet could induce a 1.4-fold increase in neutral lipids per cell [18]. This suggests that TOR inhibition could be a route to increasing TAG productivity in some algae. The TOR signaling network plays a key role in the regulation of cell growth integrating the responses to a variety of signals, like nutrient levels and stress, and transmitting them to the metabolic machinery (reviewed in $[19,20])$. TOR is a large protein kinase belonging to the phosphatidylinositol kinaserelated kinase (PIKK) family that includes the checkpoint kinases ataxia telangiectasia mutated (ATM) and ATM- and RAD3-related protein (ATR), which are master controllers of cell cycle signaling pathways [21]. TOR can be found in two multiprotein complexes, TORC1 and TORC2 [19]. While TORC2, involved in cytoskeletonorganization in animals and yeast, is not conserved in Viridiplantae and diatoms, TORC1 is found in all eukaryotes, with the exception of intracellular parasites, thus indicating a fundamental role for TORC1 in eukaryotes [22]. TORC1 is stimulated by nutrients and inhibited by stress-related signals [23]. The conserved function of 
active TORC1 is to activate protein synthesis, cell-cycle progression, and energy metabolism, while inhibiting stress responsive genes and autophagy. In yeast and animal cell lines, TOR inhibition blocks cell division, increases autophagy resulting in altered cell physiology, fate and morphology in manner reminiscent of a nutrientstarvation response [24]. In addition to a potential application in biofuel production, the study of TOR signaling in diatoms is of fundamental importance as the evolution of the TOR pathway in algae with secondary plastids might have been influenced by the multiple endosymbiosis events that characterized their evolution [9].

In this study, we used a synthetic and highly specific ATP-competitive inhibitor of the TOR kinase known as AZD-8055 [28] to test how modulating TOR activity affects cell proliferation, TAG accumulation and productivity, and primary metabolism in $P$. tricornutum. Two other TOR inhibitors, rapamycin and WYE-132, were also used to evaluate the specificity of this response towards TOR inhibition.

\section{Materials and methods}

\subsection{Algal strain and AZD-8055 treatment}

P. tricornutum Pt1_8.6 (RCC 2967) was grown for eight days at $18^{\circ} \mathrm{C}$ in $\mathrm{F} / 2$ medium [29]supplemented with silica ( $F / 2+$ Si medium) in an incubator equipped with a shaking plate (Innova 4230, New Brunswick Scientific, Edison NJ, USA). Irradiance was kept at $80 \mathrm{~mol}$ photons $\mathrm{m}^{-2} \mathrm{~s}^{-1}$ for $14 \mathrm{~h}$ day $^{-1}$. For the AZD-8055 treatments, a culture of $P$. tricornutumfrom an early exponential phase was diluted to $\mathrm{OD}_{750} \approx 0.003$ in a 5 -I Erlenmeyer flask containing $2.5 \mathrm{I}$ of fresh $\mathrm{F} / 2+\mathrm{Si}$ medium. The $\mathrm{OD}_{750}$ was measured daily until it reached $\approx 0.03$ (after $72 \mathrm{~h}$ ), a value corresponding to the beginning of the exponential phase for this strain; the culture was then split into nine 1-I Erlenmeyer flasks containing $250 \mathrm{ml}$ of medium each. The TOR inhibitor AZD-8055 (Chemdea, Ridgewood, NJ, USA; [28]) was then added to a final concentration of $0.001,0.01,0.1,1,2,4$ and $10 \mathrm{~mol} \mathrm{I}^{-1}$. The inhibitor was dissolved in dimethyl sulfoxide (DMSO), whose final concentration was adjusted to $0.1 \%$ for each of the different cultures and the control. The ninth part of the initial culture was subjected to nitrogen starvation. For $\mathrm{N}$ starvation, cells were centrifuged at $3500 \mathrm{~g}$ for $15 \mathrm{~min}$, the supernatant discarded and the pellet washed three times in $\mathrm{N}$-free $\mathrm{F} / 2+\mathrm{Si}$ medium; the pellet was then resuspended in $250 \mathrm{ml}$ of fresh $\mathrm{N}$-free $\mathrm{F} / 2+\mathrm{Si}$ medium. Three independent experiments were conducted for each culture condition. Another set of experiments was performed to compare the effect of high concentrations of AZD-8055 and other TOR inhibitors on cell proliferation and neutral lipid content in P. tricornutum. Cultures were grown as described above. The TOR inhibitors AZD-8055 (10 and $40 \mathrm{~mol} \mathrm{I}^{-1}$ ), rapamycin (10 mol I- ; LC Laboratories, Woburn, MA, USA) and WYE-132 
( $5 \mathrm{~mol} \mathrm{I}^{-1}$; Chemdea, Ridgewood, NJ, USA) were added to early exponential phase cells as described above.

\subsection{Cell fixation and Nile red staining}

Each day a volume of $P$. tricornutum culture, varying from 5 to $200 \mathrm{ml}$ depending on biomass production, was harvested by centrifugation at $3500 \mathrm{~g}$ for $15 \mathrm{~min}$. The pellet was resuspended in $0.5 \mathrm{ml}$ of a fixing solution containing HEPES $\left(0.1 \mathrm{~mol} \mathrm{I}^{-1}, \mathrm{pH} 7\right)$, $\mathrm{CaCl}_{2}\left(0.01 \mathrm{mmol}^{-1}\right), \mathrm{MgCl}_{2}\left(0.01 \mathrm{mmol}^{-1}\right)$ and glutaraldehyde $2 \%(\mathrm{v} / \mathrm{v})$. After one hour incubation at $4{ }^{\circ} \mathrm{C}$ in the dark, the fixing solution was removed and the cells resuspended in $1 \mathrm{ml}$ of HEPES $\left(0.1 \mathrm{~mol} \mathrm{I}^{-1}, \mathrm{pH} 7\right)$. The samples were stored at $4{ }^{\circ} \mathrm{C}$ in the dark.

For visualization of neutral lipids, the fixed cells were incubated with a Nile red solution (FluoProbes, Interchim; 488-530/575-580 nm excitation/emission; [30]) and analyzed by fluorescence microscopy and analytical flow cytometry. A $0.25 \mathrm{mg} \mathrm{ml}^{-1}$ Nile red solution in DMSO was added to the fixed cell suspensions to a final concentration of $1 \mathrm{~g} \mathrm{ml}^{-1}[31]$. The mixtures were incubated at $4{ }^{\circ} \mathrm{C}$ for $5 \mathrm{~min}$ prior to analysis.

\subsection{Flow cytometry}

A benchtop flow cytometer (BD Accuri C6, BD Biosciences, Ann Arbor, MI, USA) was used to assess $P$. tricornutum cell abundance during the whole course of the experiments. The instrument is equipped with two excitation laser beams emitting at 488 and $640 \mathrm{~nm}$. The flow cytometer measures chlorophyll red fluorescence (CHL, $>675 \mathrm{~nm}$; channel FL3), orange fluorescence (PE, $585 \pm 20 \mathrm{~nm}$; channel FL2), green fluorescence $(530 \pm 15 \mathrm{~nm}$; channel FL1), side scatter (SSC, light scattered by particles at $90^{\circ}$ to the direction of the laser beam) and forward light scatter (FSC, light scattered by particles at narrow angles in the same direction as the laser beam). Their combination allows detecting different wavelength emission ranges [32]. Diatom density was estimated by the cytogram forward scatter (FSC) versus channel FL3, whereas side scatter (SSC) combined with the FL3 channel was used to estimate chlorophyll auto-fluorescence. The specific growth rate for each culture condition was calculated on the exponential portion of the growth curve, according to the equation of Monod [33]. It has been demonstrated that lipid fluorescence in microalgae estimated through the combination of Nile red staining and flow cytometry shows a positive correlation with the content of lipids quantified by thin layer chromatography [34]. We then performed flow cytometry analyses on the fixed cell after Nile red staining in order to assess neutral lipid content in $P$. tricornutum. In this case, the trigger signal was set up on FL2 fluorescence and combined with the SSC signal. For all measurements of cell density, chlorophyll and lipid fluorescence the cytometer flow rate was kept constant at $35 \mathrm{I} \mathrm{min}^{-1}$. All data were normalized using 
BD TruCount beads; a $50 \mathrm{ml}$ aliquot containing a known number of beads diluted in ultrapure water (Carlo Erba Reagents, Milan, Italy) was added to each sample and the bead abundance and fluorescence measured simultaneously with those of the microalgae. Control of the cytometer, measurements of light scatter and fluorescence intensities, data storage in list mode format and subsequent data analysis were performed using the CFlow Plus software (BD Biosciences) with log amplification on a seven-decade scale.

\subsection{Epifluorescence microscopy}

In order to confirm the presence of oil bodies in AZD-8055 treated cells, fixed and Nile red-stained cells of $P$. tricornutum from each culture condition were observed under an epifluorescence microscope (Axiovert 200M, Carl Zeiss Microscopy GmbH, Jena, Germany) at an excitation wavelength of $\approx 480 \mathrm{~nm}$. At least three random pictures per sample were acquired. Nile red and chlorophyll fluorescence were adjusted to the background a posteriori using the AxioVision image-processing software version 4.8.2SP2.

\subsection{Lipid extraction, quantification and productivity}

At day 5 of growth and for each culture condition, approx. $150 \mathrm{ml}$ of cell culture was harvested by centrifugation at $3500 \mathrm{~g}$ for $15 \mathrm{~min}$ at $4^{\circ} \mathrm{C}$ in order to carry out lipid quantification. The pellets were directly resuspended in $3 \mathrm{ml}$ of a chloroform/methanol mixture $(2: 1, \mathrm{v} / \mathrm{v})$ and $0.2 \mathrm{ml}$ of $1 \mathrm{~mol} \mathrm{I}^{-1} \mathrm{HCl}$ and frozen at $-20^{\circ} \mathrm{C}$. This procedure prevents artefactual lipolysis that often occurs upon cell disruption. A freezing/thawing step followed by vigorous vortex stirring and sonication with 10 pulses for 10 times using an ultrasonicator (Sonic 671 Ruptor 250, OMNI International, Kennesaw, GA, USA) further allowed breaking the diatom cells. The samples were then mixed with $0.5 \mathrm{ml}$ of ultrapure water and stirred vigorously to complete lipid extraction. The mixtures were centrifuged at $1000 \mathrm{~g}$ for $10 \mathrm{~min}$ at $4{ }^{\circ} \mathrm{C}$ to allow complete phase separation; the lower organic phase containing lipids was collected and dried over anhydrous $\mathrm{MgSO}_{4}$ to trap residual water. The clear organic phase was collected, transferred to a 5-ml glass vial and evaporated under a nitrogen stream. The dried lipid extracts were kept at $-20^{\circ} \mathrm{C}$ before analysis. Neutral lipids were separated by thin layer chromatography on silica-coated quartz rods (SIII Chromarods) and detected by flame ionization using a MK-6 latroscan TLC-FID apparatus (latron Laboratories, Tokyo, Japan) as described previously [35]. Data acquisition and processing were performed using the i-Chromstar 6.3 integration software (SCPA GmbH, Bremen, Germany). The amounts of TAGs, free fatty acids (FFAs), monoacylglycerols (MAGs), diacylglycerols (DAGs) and free sterols were estimated from calibration curves established, respectively, with pure triolein, oleic 
acid, 1-monoolein, 1,2(2,3)-diolein, [35] and cholesterol [36] as reference standards. Sterols were also separated by classical TLC and analyzed by gas chromatography coupled to mass spectrometry (GC-MS) for identification. Total lipid extracts were first loaded and separated on a thin-layer Silica Gel 60 plate $(10 \times 20 \mathrm{~cm}$ from Merck) using a hexane/diethyl ether/acetic acid (60:40:1; v/v/v) solvent mixture. The silica band corresponding to sterols on the TLC plate was scrapped and washed with chloroform/methanol $(2: 1 \mathrm{v} / \mathrm{v})$ to recover the sterols. After solvent evaporation under nitrogen, sterols were derivatized using $100 \mu \mathrm{l}$ Bis(trimethylsilyl)trifluoroacetamide (BSTFA) at $80^{\circ} \mathrm{C}$ for $30 \mathrm{~min}$. Samples were then analyzed by GC-MS using an Agilent Technologies HP 6980 gas chromatograph equipped with a (50\%-phenyl)methylpolysiloxane $(60 \mathrm{~m} \times 0.25 \mathrm{~mm} \mathrm{ID} \times 0.25 \mu \mathrm{m}$ film $)$ DB-17MS column and a HP5973 mass spectrometer. Separation was achieved by injecting $1 \mu \mathrm{l}$ of each derivatized sample. The carrier gas was helium at an input pressure of $119 \mathrm{kPa}$. The temperature of the split/splitless injector and interface was set at $280^{\circ} \mathrm{C}$. The oven temperature was kept at $57^{\circ} \mathrm{C}$ for 2 min before ranging to $180^{\circ} \mathrm{C}$ at a rate of $20^{\circ} \mathrm{C} / \mathrm{min}$, and then to $300^{\circ} \mathrm{C}$ at a rate of $4^{\circ} \mathrm{C} / \mathrm{min}$. Temperature was then held for $30 \mathrm{~min}$ before returning to initial conditions. Mass analysis was performed with an electron impact (EI) source set at $70 \mathrm{eV}$ and $280^{\circ} \mathrm{C}$, under SCAN mode from 70 to $800 \mathrm{~m} / \mathrm{z}$, and with a quadrupole detector at $150^{\circ} \mathrm{C}$. Brassicasterol (Sigma-Aldrich B4936) was used as an external standard for quantification. Data were normalized to the cell dry weight measured from $50 \mathrm{ml}$ of $P$. tricornutum sampled at the same time the cells were harvested for lipid analysis; the pellets were washed twice with ammonium bicarbonate $0.4 \mathrm{~mol} \mathrm{I}^{-1}$ to eliminate residual salts, dried overnight at $80^{\circ} \mathrm{C}$ (Thermo Fisher Scientific, Waltham, MA USA) and finally weighed with a precision scale.

TAG productivity was calculated as described in Hempel et al. [37] using the following equation:

PTAGmgl-1day-1=PBCf

where $P_{T A G}$ is TAG productivity, $\mathrm{P}_{\mathrm{B}}$ is biomass productivity, calculated as biomass increase over time $\left(\mathrm{g} \mathrm{l}^{-1}\right.$ day $\left.^{-1}\right)$, and $\mathrm{C}_{\mathrm{f}}$ is TAG final concentration (\% of dry weight) [37].

\subsection{Protein extraction and enzyme assays}

About $250 \mathrm{ml}$ of cells, at growth day 5 after AZD-8055 addition or $\mathrm{N}$ deprivation, were collected by centrifugation at $3500 \mathrm{~g}$ for $15 \mathrm{~min}$ at $4{ }^{\circ} \mathrm{C}$. The pellets were washed twice with Tris/EDTA buffer (30 and $4 \mathrm{mmol} \mathrm{I}^{-1}$ respectively) at $\mathrm{pH} 7.9$, then resuspended in Tris/EDTA buffer plus cysteine $\left(5 \mathrm{mmol} \mathrm{I}^{-1}\right), \mathrm{NAD}^{+}\left(0.1 \mathrm{mmol}^{-1}\right)$ and protease inhibitor cocktail ( $0.5 \mathrm{mg} \mathrm{ml}^{-1}$; P2714, Sigma-Aldrich, Saint Louis, MO, USA). The cell 
suspensions were sonicated for 4 cycles, 10/30 s on/off (Sonic 671 Ruptor 250, OMNI International, Kennesaw, GA, USA), and, after the addition of $10 \%$ glycerol, centrifuged at $12000 \mathrm{~g}$ for $20 \mathrm{~min}$ at $4{ }^{\circ} \mathrm{C}$. The crude extracts were used for both total protein quantification with the Bradford assay[38] and enzyme activity measurements.

All enzyme assays were conducted at $\mathrm{pH} 7.7$ in $50 \mathrm{mmol} \mathrm{I}^{-1}$ glycylglycine, $0.5 \mathrm{mmol} \mathrm{I}^{-1}$ EDTA, $\quad 50 \mathrm{mmol} \mathrm{I}^{-1} \mathrm{KCl}$ and $15 \mathrm{mmol} \mathrm{I}^{-1} \mathrm{MgCl}_{2}$. The activities of glyceraldehyde phosphate dehydrogenase (GAPDH), glucose-6-phosphate dehydrogenase (G6PDH) and malate dehydrogenase $(\mathrm{MDH})$ were measured spectrophotometrically at $340 \mathrm{~nm}$ as described in Mekhalfi et al. [8].

\subsection{Data analysis and statistics}

All graphs and statistical tests were performed with SigmaPlot version 11.0 (Systat Software, Chicago, IL, USA). Error bars correspond to standard deviations calculated on three biological and three technical replicates. Statistical significance was calculated using the analysis of variance (one-way ANOVA) followed by the HolmŠídák multiple comparisons test.

\section{Results}

\subsection{AZD-8055 inhibits $P$. tricornutum growth in a dose-dependent manner}

The $P$. tricornutum genome contains a single TOR gene (Fig. S1). The motifs and amino acids of the ATP-binding pocket of the TOR kinase domain are highly conserved in $P$. tricornutum compared to mammals (Fig. S2), indicating that specific ATP. competitive TOR inhibitors developed for mammalian cells should be potent in $P$. tricornutum. We tested AZD-8055 because this inhibitor is highly selective for TOR and is potent in a wide range of species, including plants and green algae [16,25]. Flow cytometry was used to directly measure the effect of AZD-8055 on cell proliferation. Treatment with AZD-8055 caused a clear inhibition of $P$. tricornutum cell proliferation in a dose responsive manner, with $30 \%$ inhibition at 2 and $4 \mu \mathrm{M}$ and $80 \%$ inhibition at $10 \mu \mathrm{M}$ (Fig. 1A). The time course of the effects of AZD-8055 on P. tricornutum growth curves and doubling times are reported in comparison with $\mathrm{N}$ starvation (Fig. 1B and Table 1). The typical growth curve of $P$. tricornutum in the control showed a 3-day lag phase followed by four days of exponential growth. The average doubling time was $17 \pm 1 \mathrm{~h}^{-1}$ during the exponential phase. AZD-8055 did not appear to affect either the growth curve shape or the growth rate at concentrations up to $1 \mathrm{~mol} \mathrm{I}^{-1}$. AZD-8055 concentrations of 2 and $4 \mathrm{~mol} \mathrm{I}^{-1}$ resulted in a modest, but reproducible, inhibition of growth and, unlike the control, these cultures had not yet reached the stationary phase after 5 days of cultivation (Fig. 1B and S3, Table 1). P. tricornutum growth was strongly and reproducibly affected by $10 \mathrm{~mol} \mathrm{I}^{-1}$ AZD-8055 with a doubling time of almost half 
that of the control (Table 1) and a final density of $20 \%$ of the control, corresponding to $80 \%$ inhibition of cell proliferation. $\mathrm{N}$ starvation had an even more drastic effect than $10 \mathrm{~mol} \mathrm{I}^{-1}$ AZD-8055 with a doubling time 3 times longer than the control and a final density of only $5 \%$ of the control, corresponding to $95 \%$ inhibition of cell proliferation (Fig. 1B and Table 1). These results show that $P$. tricornutum cell proliferation can be robustly modulated using different concentrations of the TOR inhibitor AZD-8055.

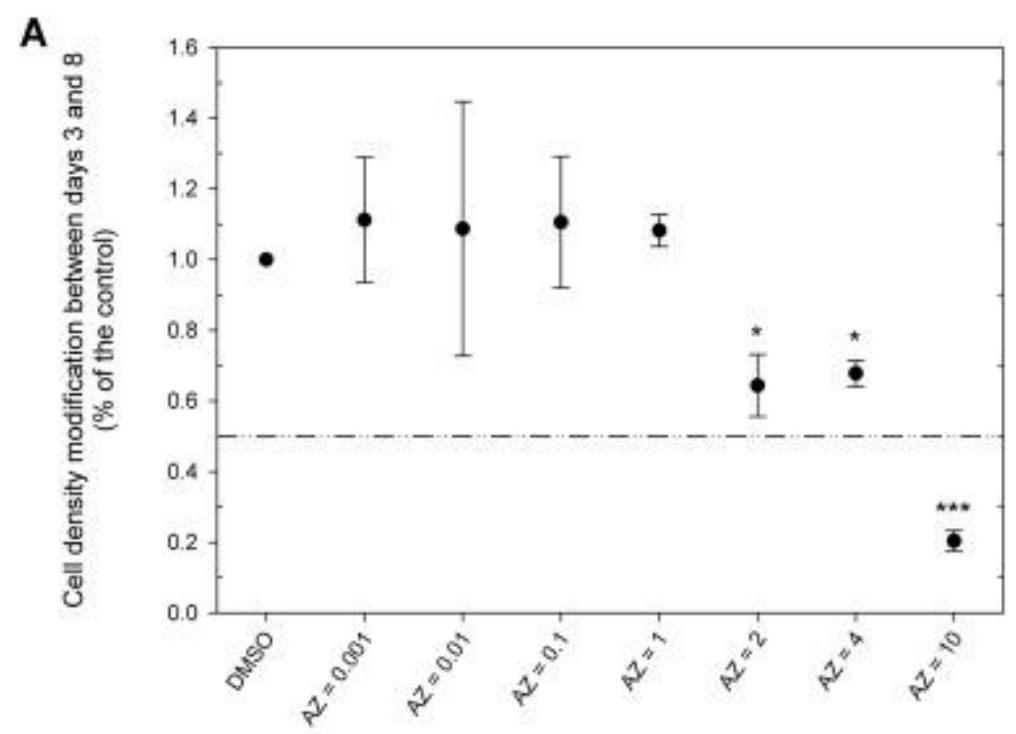

B

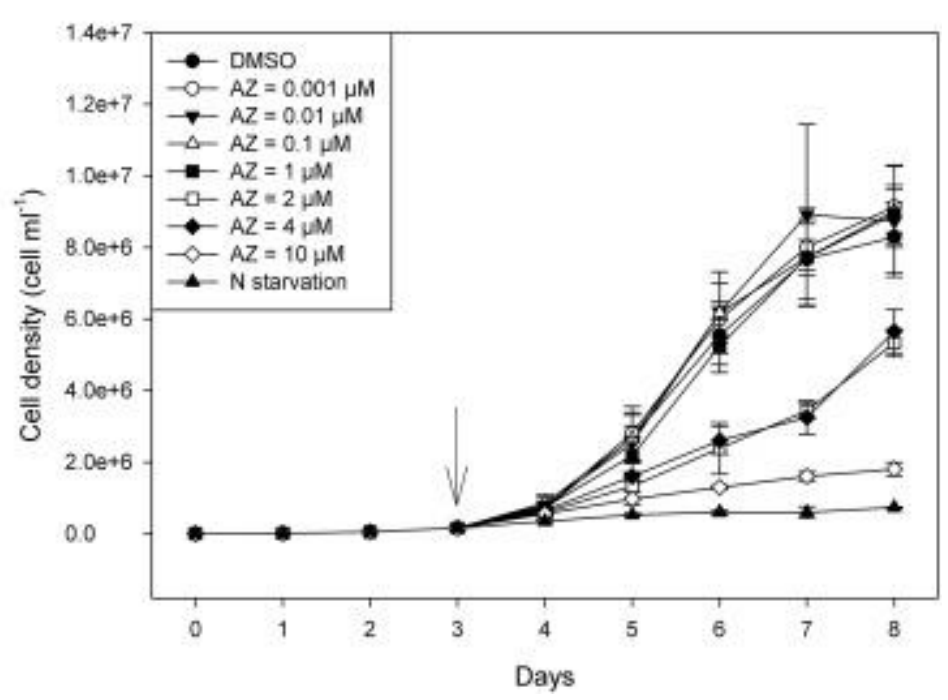

Fig. 1. AZD-8055 inhibits $P$. tricornutum cell proliferation in a dose-dependent manner. A) Dose-response curve for AZD-8055 (AZ). Means of three biological and three technical replicates are shown \pm standard deviation. Asterisks indicate statistical significance with respect to the control $\left({ }^{*}=p<0.05 ;{ }^{* *}=p<0.01 ;{ }^{* * *}=p<0.001\right)$. B) Growth curves with the corresponding cell densities. The arrow indicates the day at which the treatment as either DMSO or TOR inhibitor (AZ) addition or N starvation had started.

Table 1. Growth rates and doubling times of $P$. tricornutum under AZD-8055 (AZ) treatment or $N$ starvation. Means of three biological and three technical replicates are 
shown \pm standard deviation. Asterisks indicate statistical significance with respect to the control $\left({ }^{*}=p<0.05 ;{ }^{* *}=p<0.01 ;{ }^{* * *}=p<0.001\right)$.

$\begin{array}{lll} & \text { Growth rate }\left(\text { days }^{-1}\right) & \text { Doubling time (hours) } \\ \mathrm{DMSO} & 0.995 \pm 0.073 & 16.79 \pm 1.193 \\ \mathrm{AZ}=0.001 \mu \mathrm{M} & 1.005 \pm 0.110 & 16.68 \pm 1.761 \\ \mathrm{AZ}=0.01 \mu \mathrm{M} & 1.107 \pm 0.076 & 15.07 \pm 1.069 \\ \mathrm{AZ}=0.1 \mu \mathrm{M} & 1.077 \pm 0.132 & 15.61 \pm 2.037 \\ \mathrm{AZ}=1 \mu \mathrm{M} & 0.984 \pm 0.101 & 17.02 \pm 1.647 \\ \mathrm{AZ}=2 \mu \mathrm{M} & 0.759 \pm 0.042 & 21.96 \pm 1.213 \\ \mathrm{AZ}=4 \mu \mathrm{M} & 0.752 \pm 0.100 & 22.40 \pm 3.171 \\ \mathrm{AZ}=10 \mu \mathrm{M} & 0.559 \pm 0.119 & 30.65 \pm 6.333 \\ \mathrm{~N} \text { starvation } & 0.329 \pm 0.089 & 53.15 \pm 14.58\end{array}$

\subsection{AZD-8055 promotes the accumulation of neutral lipids in lipid droplets}

Nile red staining was used to investigate variations in neutral lipid content by flow cytometry and fluorescence microscopy. The quantification of neutral lipids by Nile red fluorescence showed a strong correlation with the quantification of TAGs by TLC-FID (Peterson $r=0.97$; Fig. S4), confirming the reliability of Nile red fluorescence as a fast and simple method to estimate neutral lipid abundance in microalgae, especially when handling large datasets [31,34]. Fluorescence analysis revealed that neutral lipid content did not vary in cells treated with AZD-8055 up to a concentration of $1 \mathrm{~mol} \mathrm{I}^{-1}$ with respect to the control (Fig. 2A). In contrast, at higher concentrations of AZD-8055 (2, 4 or $\left.10 \mathrm{~mol} \mathrm{I}^{-1}\right)$, neutral lipid accumulation was rapidly triggered and the fluorescence signal reached almost 4-fold the level of the control after one day. Neutral lipid content continued increasing at these higher AZD-8055 concentrations and reached very similar values of about 20 -fold higher at day 5 . This increase in neutral lipids was less rapid for $2 \mathrm{~mol} \mathrm{I}^{-1}$ AZD-8055 than for 4 and $10 \mathrm{~mol} \mathrm{I}^{-1}$ showing a dose dependent effect on the timing of neutral lipid accumulation. $\mathrm{N}$ starved cells showed an earlier and higher accumulation of neutral lipids with a 10-fold higher signal than the control at day 1 and 100 -fold higher at day 5 . 


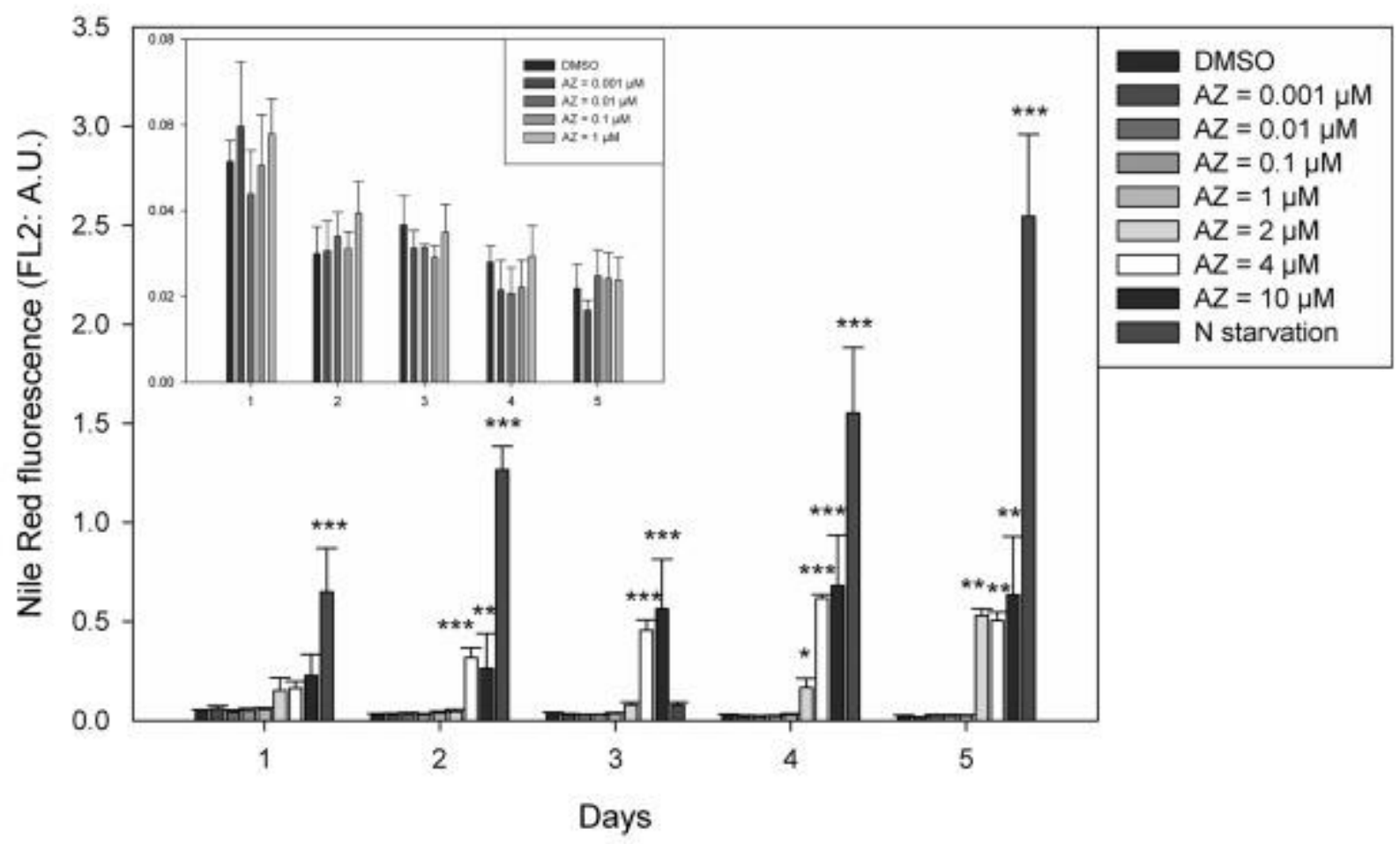

B

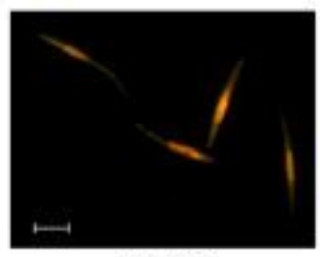

DMSO

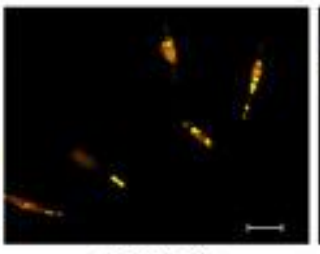

AZ $2 \mu M$

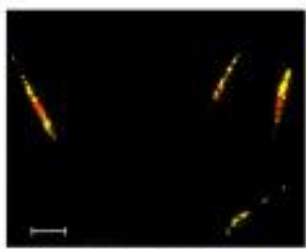

AZ $4 \mu \mathrm{M}$

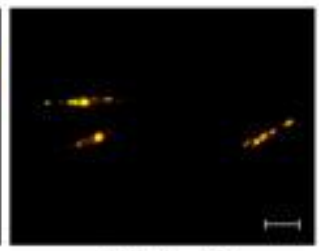

AZ $10 \mu \mathrm{M}$

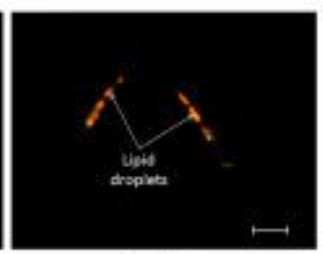

N starv

Fig. 2. Effect of $A Z D-8055$ and $N$ starvation on neutral lipid fluorescence and lipid droplet accumulation. A) Lipid estimation after Nile red staining measured with the flow cytometer. The $x$ axis depicts the days after treatment with either DMSO or AZD-8055 $(A Z)$ addition or after transfer into $\mathrm{N}$-free medium. Means of three biological and three technical replicates are shown \pm standard deviation. Asterisks indicate statistical significance with respect to the control $\left({ }^{*}=p<0.05 ;{ }^{* *}=p<0.01 ;{ }^{* * *}=p<0.001\right)$. $B)$ Fluorescence microscopy of $P$. tricornutum after Nile red staining at day 5. Lipid droplets are indicated by the yellow fluorescence, while the red fluorescence corresponds to chlorophyll auto-fluorescence. The scale bars correspond to $10 \mu \mathrm{m}$ length in all pictures. (For interpretation of the references to colour in this figure legend, the reader is referred to the web version of this article.)

These data were confirmed by fluorescence microscopy, which showed visible differences in the number and size of Nile red stained lipid droplets within cells (Fig. 2B and S5). No lipid droplets could be observed in either the control or cells treated with up to $1 \mathrm{~mol} \mathrm{I}^{-1}$ of AZD-8055 (Fig. 2B and S5). On the contrary, in cells treated with AZD-8055 2, 4 and $10 \mathrm{~mol} \mathrm{I}^{-1}$, numerous small lipid droplets appeared from the first day of treatment (Fig. S5). By the end of the experiment (Fig. 2B), lipid droplets almost filled the interior of cells that had been treated with the highest concentration of AZD- 
8055. In cells subjected to $\mathrm{N}$ starvation, large lipid droplets developed after one day of treatment and became the most prevalent part of the cell by day 5 . In summary, cells treated with 2 to $10 \mu \mathrm{M}$ AZD-8055 progressively accumulated high levels of neutral lipids in droplets, and these changes did not occur as early or as strongly as in $\mathrm{N}$ starved cells.

\subsection{AZD-8055 enhances TAG productivity compared to $N$ starvation}

Neutral lipids were extracted from early stationary phase cells collected at day 5 after addition of AZD-8055 or N starvation, separated, and quantified by TLC-FID. In agreement with flow cytometry and fluorescence microscopy data, TAG content (Fig. 3A) did not change significantly in cells treated with AZD-8055 up to $1 \mathrm{~mol} \mathrm{I}^{-1}$ compared to the control, where TAG represented $0.1 \%$ of total dry biomass. However, in cells treated with 2, 4 and $10 \mathrm{~mol} \mathrm{I}^{-1}$ of AZD-8055, TAG content reached $3-7 \%$ of total dry biomass. It is also noteworthy that the TAG contents in cells treated with the three highest concentrations of AZD-8055 were not statistically different from each other. In accordance with the flow cytometry data, TAG content was considerably higher in N-starved cells ( $24 \%$ of total dry biomass). However, for biofuel applications the quantity of TAG expressed on a per cell basis or as a percentage of dry weight is not as important as the TAG productivity of the total culture. We found that TAG productivity started to increase around $1 \mathrm{~mol} \mathrm{I}^{-1}$ AZD-8055 and strongly increased to values almost 100 times higher than control cells in cells treated with 2 to $10 \mu \mathrm{M}$ AZD8055. Strikingly, TAG productivity was much higher than for N-starved cells (about 34 times higher; Fig. 3B). This higher TAG productivity can be explained by the fact that the TOR inhibitor did not affect cell proliferation as much as $\mathrm{N}$ starvation and allowed the accumulation of a greater total biomass. Indeed, TAG productivity is maximal at AZD-8055 concentrations that reduce cell proliferation to $40-50 \%$ of the control, while $\mathrm{N}$ starvation reduces cell proliferation to $5 \%$ of the control. 
A

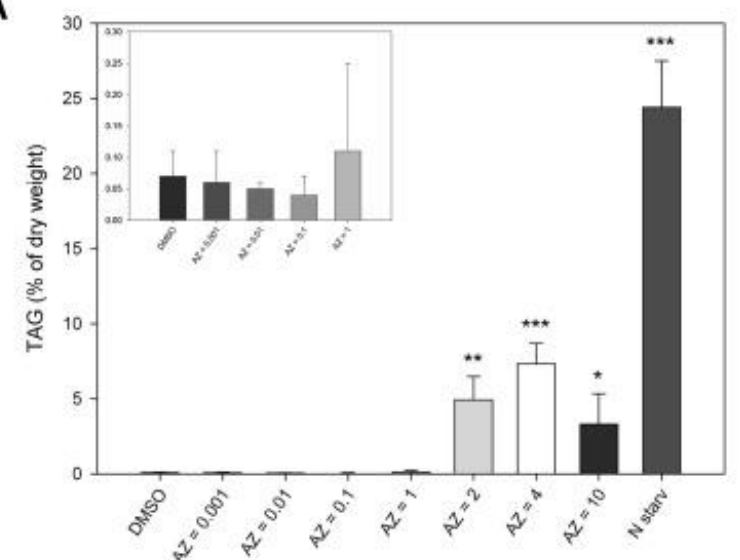

C

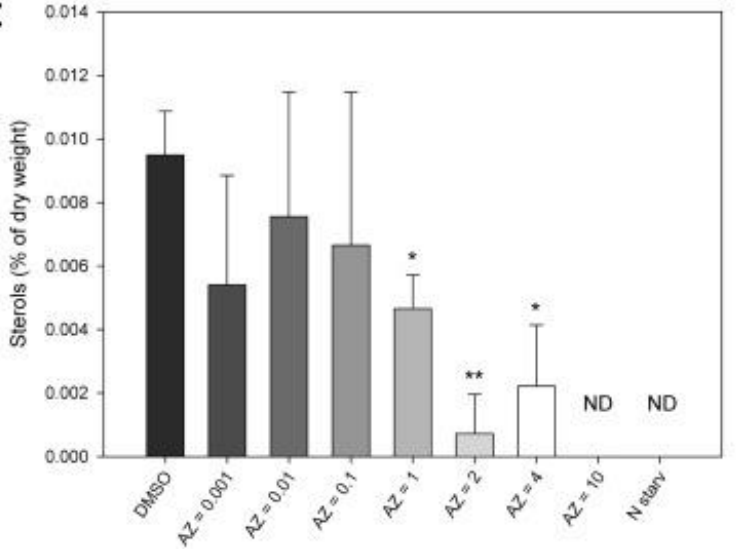

B

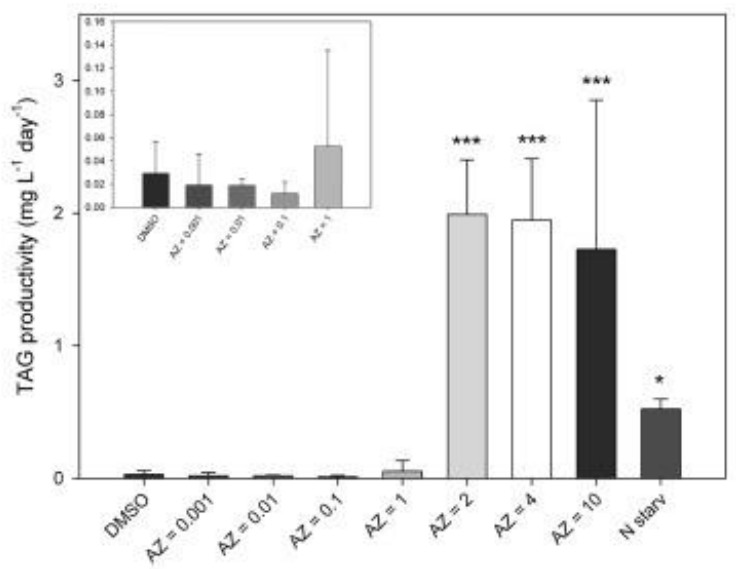

D

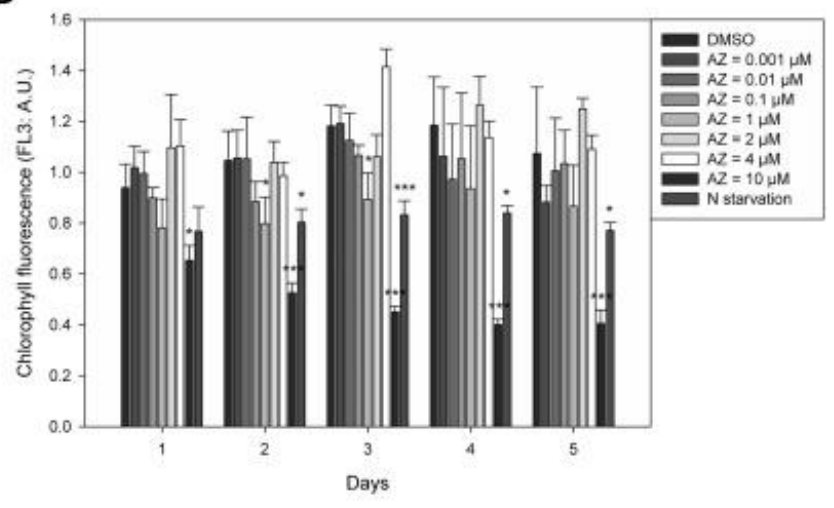

Fig. 3. Quantification of neutral lipid, sterols, and chlorophyll in batch cultures 5 days after addition of AZD-8055 (AZ) or N starvation. Neutral lipid and sterol content was estimated by TLC-FID analysis. A) Quantification of TAGs per culture batch relative to biomass. B) TAG productivity. C) Quantification of total sterols per culture batch relative to biomass. D) Chlorophyll auto-fluorescence. The means of three biological and three technical replicates are shown \pm standard deviation. Asterisks indicate statistical significance with respect to the control $\left(^{*}=p<0.05 ;{ }^{* *}=p<0.01\right.$; $\left.{ }^{* * *}=p<0.001\right)$.

\subsection{AZD-8055 decreases sterol content}

TLC-FID analysis of other neutral lipids showed low levels of free fatty acids (FFAs), monoacylglycerols (MAGs) and diacylglycerols (DAGs) (below the limit of quantification, data not shown). Only total sterols of $P$. tricornutum could be quantified based on a calibration curve established with cholesterol (Fig. 3C). GC-MS analysis confirmed that $P$. tricornutum sterols were almost exclusively constituted of brassicasterol, whatever the conditions. Compared to the control, sterol content was almost unaffected in cells treated with concentrations of AZD-8055 at or below $0.1 \mathrm{~mol} \mathrm{I}^{-1}$, but decreased significantly at AZD-8055 concentrations of 1,2 and $4 \mathrm{moll}^{-1}$. Compared to the dose response curve of TAG content, the sterol dose response was shifted to lower AZD-8055 concentrations, suggesting that inhibition of 
sterol accumulation precedes TAG accumulation. At an AZD-8055 concentration of $10 \mathrm{~mol} \mathrm{I}^{-1}$, the level of sterols became too low to be quantified, as was also observed for cells under $\mathrm{N}$ starvation. High concentrations of AZD-8055 and N starvation, therefore, provoked a large decrease in total sterol/brassicasterol content while TAG accumulated. This reveals a correlation between the decrease in sterols and growth inhibition and an inverse correlation between the accumulation of TAGs and sterols.

\subsection{AZD-8055 reduces chlorophyll fluorescence more strongly than $N$ starvation}

During the microscopic observation of Nile red stained cells, we observed less chlorophyll fluorescence from the chloroplasts of cells treated with high concentrations of AZD-8055 (Fig. 2B). This led us to analyze variations in $P$. tricornutum chlorophyll fluorescence in response to the treatment with AZD-8055 and $\mathrm{N}$ starvation (Fig. 3D). Chlorophyll fluorescence did not vary significantly in cells treated with AZD-8055 at concentrations up to $4 \mathrm{~mol} \mathrm{I}^{-1}$. However, at $10 \mathrm{~mol} \mathrm{I}^{-1}$ AZD-8055 the average chlorophyll fluorescence was significantly lower from the first day after treatment and progressively decreased to less than half the level of the control at day 5. In cells subjected to $\mathrm{N}$ starvation, chlorophyll fluorescence decreased slightly but significantly 1 day after treatment and remained constant for the following days. Therefore, despite the more drastic growth inhibition, $\mathrm{N}$ starved cells maintained twofold higher chlorophyll fluorescence than cells treated with $10 \mu \mathrm{M}$ AZD-8055. This higher chlorophyll fluorescence may at least partially explain why, although present, clear lipid droplets (bright yellow) were not visible in all N starved cells (Fig. 2B and S4). Interestingly, these data also show that high TAG productivity is not associated with higher chlorophyll content.

\subsection{Effect of $A Z D-8055$ and $N$ starvation on P. tricornutum metabolism}

The activity of several metabolic enzymes was analyzed after 5 days of AZD-8055 treatment or $\mathrm{N}$ starvation. The activity of the $\mathrm{NAD}^{+}$-dependent glyceraldehyde 3phosphate dehydrogenase (GAPDH) from glycolysis decreased significantly (>2-fold) following AZD-8055 treatment (Fig. 4A) and showed a dose response effect from $0.1 \mathrm{moll}^{-1}$. On the contrary, GAPDH activity increased significantly under $\mathrm{N}$ starvation, suggesting that the two treatments may have different effects on glucose metabolism. The activity of malate dehydrogenase (MDH) from the Krebs cycle (Fig. 4B) was not affected in cells treated up to $2 \mathrm{~mol} \mathrm{I}^{-1}$ AZD-8055 and increased significantly (2-3 fold higher than the control) in cells treated with the highest AZD8055 concentrations ( 4 and $10 \mathrm{~mol} \mathrm{I}^{-1}$ ) as well as in cells subjected to $\mathrm{N}$ starvation. The activity of glucose-6-phosphate dehydrogenase (G6PDH) from the pentose phosphate pathway (Fig. 4C) was not affected in cells treated with up to $4 \mathrm{~mol} \mathrm{I}^{-1}$ of 
AZD-8055, but at $10 \mathrm{~mol} \mathrm{I}^{-1}$ of AZD-8055, we observed a significant increase of $>10$ fold with respect to the control. The increase in G6PDH activity under $\mathrm{N}$ starvation was similar to that obtained with the highest AZD-8055 concentration and was around 20fold higher than in the control. The different activities of GAPDH in cells treated with AZD-8055 or N-starvation are intriguing and suggest that, despite other similarities, these treatments may have distinct effects on the primary metabolism of $P$. tricornutum, although this needs further investigation.

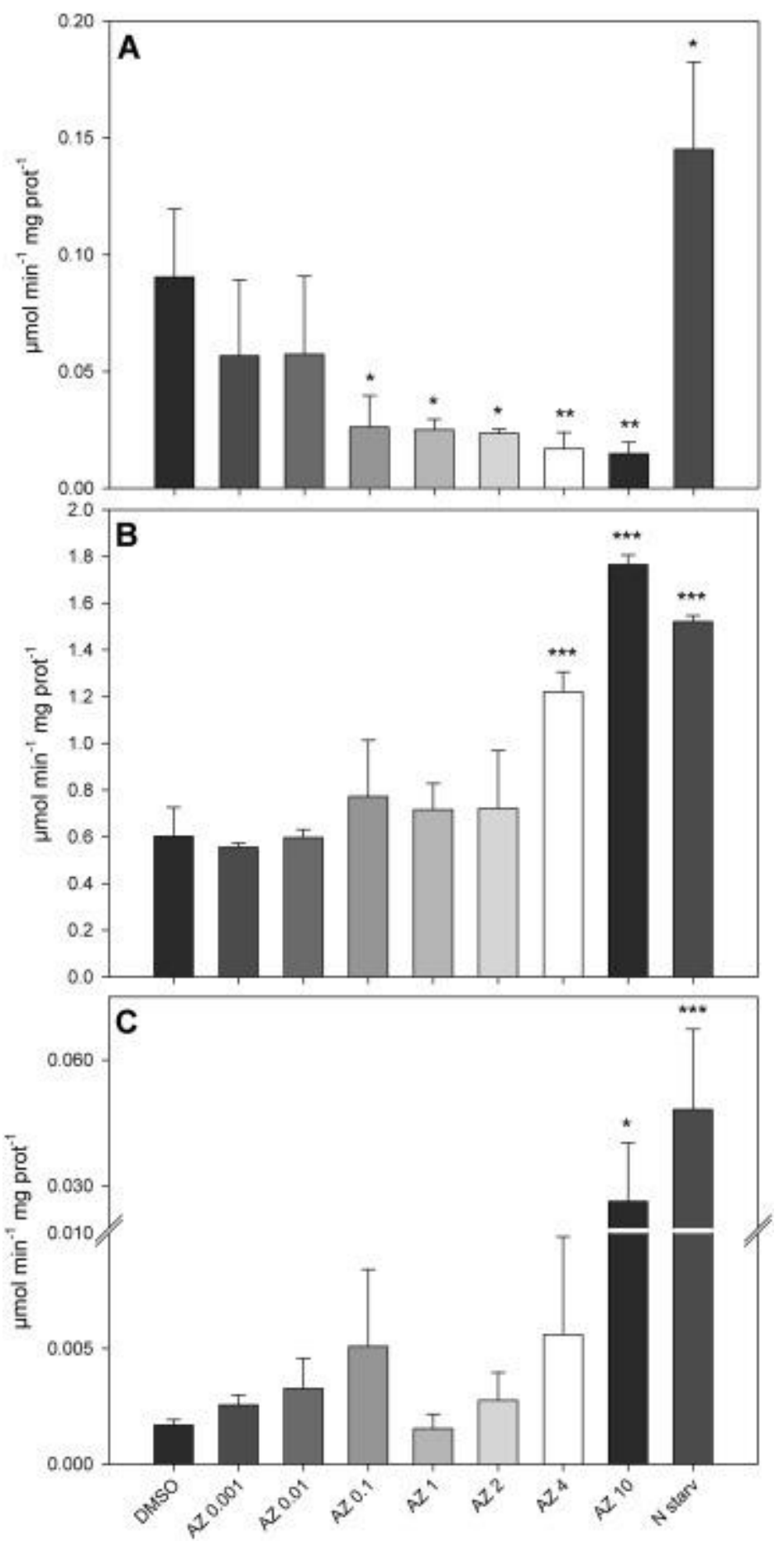


Fig. 4. Activity of metabolic enzymes in crude extracts from P. tricornutum cells 5 days after AZD-8055 (AZ) treatment or N starvation. A) NAD+-dependent glyceraldehyde-3phosphate dehydrogenase $(G A P D H), \quad B)$ malate dehydrogenase $(M D H)$ and C) glucose-6-phosphate dehydrogenase (G6PDH). The means of three biological and three technical replicates are shown \pm standard deviation. Asterisks indicate statistical significance with respect to the control $\left({ }^{*}=p<0.05 ;{ }^{* *}=p<0.01 ;{ }^{* \star *}=p<0.001\right)$.

3.7. WYE-132, another specific ATP-competitive TOR inhibitor inhibits cell proliferation and promotes TAG accumulation in P. tricornutum

We tested other TOR inhibitors to confirm that the effects of AZ-8055 on cell proliferation (Fig. 5A) and neutral lipid accumulation (Fig. 5B) are specific to the inhibition of TOR. We found that rapamycin $(10 \mu \mathrm{M})$ did not have a significant effect on cell proliferation with respect to the control and did not induce lipid accumulation. Problems with the potency of rapamycin have been reported in other photosynthetic organisms and we did not test higher concentrations of rapamycin as it leads to precipitates that could preclude clear conclusions [25-27]. The selective ATP-competitive TOR inhibitor WYE-132, which has been shown to be highly potent in plants [25], drastically inhibited cell proliferation and induced neutral lipid accumulation. These results were similar to those obtained when cells are deprived of $\mathrm{N}$ or exposed to high concentrations of AZD-8055 $(40 \mu \mathrm{M})$. This indicates that WYE132 is 10 times more potent than AZD-8055, as in plants [25], and that WYE-132 causes similar effects on cell proliferation and neutral lipid accumulation. These results strongly suggest that these effects are a specific response to the direct inhibition of TOR. Our observation that high concentrations of TOR inhibitors strongly inhibit cell proliferation suggests that under these conditions $P$. tricornutum TOR is fully inhibited. However, neutral lipid accumulation reached similar values at $10 \mu \mathrm{M}$ and $40 \mu \mathrm{M}$ AZD8055 (Fig. 5B), suggesting that a concentration $\leq 10 \mu \mathrm{M}$ is sufficient to induce a maximum effect on lipid synthesis without completely impairing cell proliferation. 


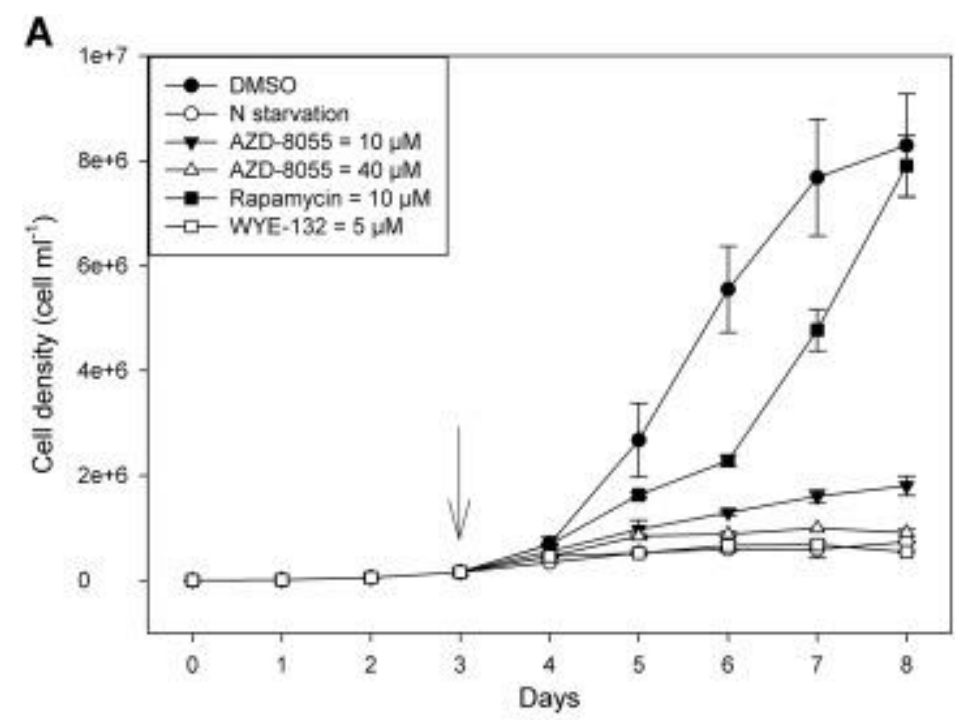

B

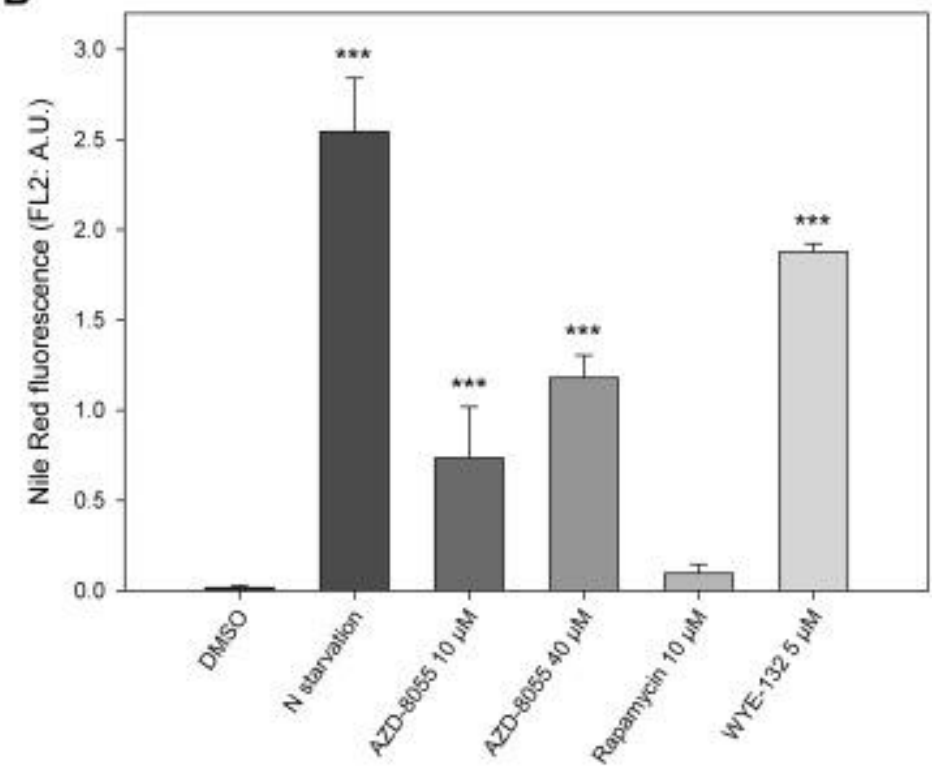

Fig. 5. Effect of different inhibitors of TOR and $N$ starvation on $P$. tricornutum cell proliferation and neutral lipid fluorescence. A) Growth curves with the corresponding cell densities. The arrow indicates the day at which the treatment started. B) Lipid estimation after Nile red staining measured with the flow cytometerat 5 days after treatment. Means of at least three biological replicates are shown \pm standard deviation. Asterisks indicate statistical significance with respect to the control $\left(^{*}=p<0.05\right.$; ${ }^{* *}=p<0.01 ;{ }^{* * *}=p<0.001$ ). (For interpretation of the references to colour in this figure legend, the reader is referred to the web version of this article.)

\section{Discussion}

It is widely recognized that microalgae can produce large amounts of lipids under certain stress conditions, most notably nutrient limitation, and that they are attractive for biofuel production [3]. Nevertheless, while redirecting energy towards lipid synthesis, the stressed microalgae also interrupt cell division [14]. As a consequence, 
the final lipid yield per culture is limited to the number of cells present when the lipidinduction process is initiated, even though cells accumulate neutral lipids as a large part of their biomass. This is one of the reasons why the production of third generation biofuels on a large scale is still not economically viable. In this work, we investigated whether the inhibition of TOR, a key player in the control of metabolic homeostasis and lipid biosynthesis [15,39,40], could promote "get-fat growth" in $P$. tricornutum, a regime under which lipid accumulation is promoted while maintaining cell proliferation. Our work was the first attempt to inhibit the TOR kinase in a diatom. Rapamycin did not robustly inhibit $P$. tricornutum cell proliferation confirming that this allosteric inhibitor is generally less efficient in photosynthetic organisms than it is in yeast and mammalian cells[25]. The two specific ATP-competitive inhibitors of TOR, AZD-8055 and WYE-132, which have unrelated molecular structures and are potent in plants [25], inhibited $P$. tricornutumcell proliferation in accordance with the essential function of TOR in the regulation of cell growth and division, conserved in all organisms. Both TOR inhibitors also induced neutral lipid accumulation supporting the specificity of this response towards TOR inhibition. We focused our detailed analysis on AZD-8055 treatments because it has been shown to be effective in a large range of species of Viridiplantae including Arabidopsis thaliana, Nicotiana benthamiana, Lotus japonicus, Panicum miliaceum and Oryza sativa, [25] as well as in the microalga $C$. reinhardtii[16]. AZD-8055 is a potent ATP-competitive inhibitor of the mammalian TOR kinase that shows a high selectivity for mTOR and has almost no effect on other kinases including the closely related PIKK family members ATM, ATR and DNAPK[28]. Our demonstration here that AZD-8055 is potent in a diatom strongly suggests that AZD-8055 can be used to study the TOR pathway in evolutionary distantly-related organisms as inhibition proceeds through the active site of the kinase, which is usually conserved among species. Indeed, we report here that the kinase domain of $P$. tricornutumTOR is closer to the corresponding domain in mammals than even flowering plants (Fig. S1). Our phylogenetic data thus suggests that it was the TOR kinase of the bikont host that was retained after the secondary endosymbiosis of red algae. Treatment of $P$. tricornutum cells with AZD-8055 resulted in a reproducible dose dependent inhibition of cell proliferation (Fig. 1A). Inhibition of proliferation was accompanied by an increase in TAG (Fig. 3A) and a decrease in sterols (Fig. 3C) and chlorophyll fluorescence (Fig. 3D). A similar inverse relationship between TAG and sterol production has been reported in photosynthetic [41,42]and nonphotosynthetic organisms [43]. Sterols are usually more abundant during the exponential phase of cell growth when there is a high demand for lipids for membrane synthesis [44]. AZD-8055 caused a decrease in sterol levels even at concentrations that did not alter cell proliferation, suggesting that $P$. tricornutum sterol metabolism 
may be highly sensitive to TOR activity (Fig. 3C). The most abundant and almost only sterol found in $P$. tricornutum is epibrassicasterol (24a-methylcholesta-5,22E-dien-3 $\beta$ ol or diatomsterol; [45]). Our data are in agreement with these findings and, while we found strong inhibition of free sterol accumulation in response to AZD-8055 and Nstarvation, we did not observe any changes in sterol composition. Interestingly, cells treated with $10 \mu \mathrm{M}$ AZD-8055 had lower chlorophyll fluorescence than $\mathrm{N}$-starved cells (Fig. 3D), despite a higher rate of proliferation. A study of $A$. thaliana plants treated with AZD-8055 reported the bleaching of leaves accompanied by the downregulation of genes involved in chlorophyll biosynthesis and an upregulation of genes involved in chlorophyll breakdown [46]. This suggests that the $P$. tricornutum TOR kinase has acquired similar functions to the plant TOR kinase in the control of chlorophyll metabolism, despite their different evolutionary histories. The AZD-8055 dose response curve also allowed us to reveal that AZD-8055 can promote a much higher TAG productivity than $\mathrm{N}$ starvation (Fig. 3B). This is because TAG could be induced at levels of AZD-8055 that reduced but did not stop proliferation as occurs in N starved cells. Recent studies show that the induction of TAG accumulation upon TOR inactivation appears to be a common trait in different types of organisms, both photosynthetic [15-18] and heterotrophic [47]. However, inhibition of TOR for the modulation of TAG productivity has not been clearly investigated. Indeed, the rapamycin concentration used to promote TAG accumulation in red and green algae almost completely inhibits cell proliferation $[17,26,48]$. Interestingly, rapamycin did slightly increase neutral lipids per cell in Euglena gracilis at a concentration that also had little effect on proliferation [18]. Taken together with our demonstration here that TAG productivity is promoted by treatment with AZD-8055 in $P$. tricornutum, this strongly suggests that increased TAG productivity may be a common response of algae to partial TOR inhibition. We looked for the effect of AZD-8055 on the activities of metabolic enzymes representative of central pathways for cell physiology. We measured the activity of GAPDHfrom glycolysis, of G6PDH from the oxidative pentose phosphate pathway and MDH from the Krebs cycle. Previous studies showed that these enzymes have a connection with lipid metabolism in nutrient limited microalgae $[8,49,50]$. Enzyme activities were measured in AZD-8055 treated cells and cells under $\mathrm{N}$ starvation to determine whether similar metabolic responses underlie TAG accumulation under these two conditions. The activity of GAPDH clearly decreased in AZD-8055 treated cells while it increased in response to $\mathrm{N}$ starvation. The increase in GAPDH activity under N-starvation is consistent with previous studies showing that the transcript levels of GAPDH_3, which encodes the cytosolic GAPDH, increase in response to $\mathrm{N}$-starvation $[51,52]$. Increased GAPDH is also consistent with increased TAG accumulation because the final products of glycolysis 
are ATP and pyruvate, the primary sources of energy and carbon for lipid synthesis [53]. It is therefore all the more surprising that AZD-8055 treatment simultaneously inhibited glycolysis and promoted TAG accumulation. The impaired glycolytic reactions under TOR inactivation, even at low concentrations of AZD-8055, suggest that the TOR signaling cascade may have a direct effect on sugar metabolism. A direct correlation between mTOR and glycolytic activity has been observed in different animal cell lines [54-57]. The activities of G6PDH and $\mathrm{MDH}$, as for cell proliferation, were affected only at the highest concentrations of AZD-8055 and increased to values comparable with those of cells under $\mathrm{N}$ starvation. This is consistent with previous transcriptomics analyses showing increased accumulation of transcripts coding for enzymes of the Krebs cycle and the pentose phosphate pathway upon $\mathrm{N}$ starvation in $P$. tricornutum[51]. Furthermore, a correlation between the activity of G6PDH and MDH and TAG synthesis has previously been demonstrated $[8,50]$. The higher activity of G6PDH probably provides a stock of NADPH that could be used for lipid synthesis. On the other hand, a higher MDH activity may reflect a higher activity of the whole Krebs cycle, supplying the lipid biosynthesis pathway with carbon skeletons (e.g. citrate for the synthesis of cytosolic acetyl-CoA; [53]). In summary, the enzyme activity assays and measures of chlorophyll fluorescence show that AZD-8055 treatment and $\mathrm{N}$-starvation provoke both common and divergent metabolic responses. Notably, in animals and yeast TOR activity is inhibited by low nitrogen availability [57]. If this is also the case in $P$. tricornutum then it suggests that $\mathrm{N}$ starvation, in addition to also potentially inhibiting TOR, may also activate other signaling pathways to promote TAG accumulation. Further studies are, therefore, clearly required to better understand the different mechanisms that appear to orchestrate TAG production under TOR inhibition and $\mathrm{N}$-starvation.

As we have shown, AZD-8055 treatment has multiple effects on cell physiology and metabolism in $P$. tricornutum. In particular, we found that the specific TOR kinase inhibitor AZD-8055 had dose dependent effects on cell proliferation, lipid homeostasis, chlorophyll accumulation and carbon metabolism. The TOR pathway is still under study in plants and has so far received little attention in diatoms [58]. The direct targets of TOR involved in downstream signaling cascades, gene transcription, and protein synthesis remain to be discovered. Our finding that, in contrast to other TOR inhibitors, the inhibition of the TOR kinase at intermediate concentrations of AZD-8055 promotes high TAG productivity while reducing but not halting cell proliferation, paves the way for new studies on TOR signaling in diatoms as well as for the chemical and metabolic engineering of algae for high lipid production. 


\section{Acknowledgements}

The authors thank Artemis Kosta and Hugo Le Guenno from the Platform of Microscopy of IMM (CNRS Marseille) and Carine Puppo (BIP, UMR 7281, CNRS Marseille) for their expertise in microscopy and help analyzing pictures. Laura Sams from EIPL lab (IMM, UMR 7282, CNRS Marseille) for her support in lipid analysis by TLC-FID. Nathalie Bernoud-Hubac, Michel Guichardant and Baptiste Fourmaux from the IBiSA Functional Lipidomics Platform (IMBL-INSA Lyon, France) for sterol analysis by GC-MS. This work was supported by the ANR SIGNAUX BioNRJ (ANR-15-CE050021-03) and the $A^{*}$ MIDEX project ( $n^{\circ}$ ANR-11-IDEX-0001-02) funded by the «Investissements d'Avenir» French Government program, managed by the French National Research Agency (ANR).

\section{References}

1 T.R. Anderson, E. Hawkins, P.D. Jones

$\mathrm{CO}_{2}$, the greenhouse effect and global warming: from the pioneering work of Arrhenius and Callendar to today's Earth System Models

Endeavour, 40 (2016), pp. 178-18

2 X. Morelli, C. Rieux, J. Cyrys, B. Forsberg, R. Slama

Air pollution, health and social deprivation: a fine-scale risk assessment

Environ. Res., 147 (2016), pp. 59-70

3 Y. Chisti

Biodiesel from microalgae

Biotechnol. Adv., 25 (2007), pp. 294-306

4 C.B. Field, M.J. Behrenfeld, J.T. Randerson, P. Falkowski

Primary production of the biosphere: integrating terrestrial and oceanic components Science, 281 (1998), pp. 237-240

5 Z.V. Finkel, M.J. Follows, J.D. Liefer, C.M. Brown, I. Benner, A.J. Irwin Phylogenetic diversity in the macromolecular composition of microalgae PLoS One, 11 (2016), Article e0155977

\section{E.V. Armbrust}

The life of diatoms in the world's oceans

Nature, 459 (2009), pp. 185-192

7 O. Levitan, J. Dinamarca, G. Hochman, P.G. Falkowski

Diatoms: a fossil fuel of the future 
Trends Biotechnol., 32 (2014), pp. 117-124

8 M. Mekhalfi, S. Amara, S. Robert, F. Carriere, B. Gontero

Effect of environmental conditions on various enzyme activities and triacylglycerol contents in cultures of the freshwater diatom, Asterionella formosa (Bacillariophyceae) Biochimie, 101 (2014), pp. 21-30

9.C. Bowler, A.E. Allen, J.H. Badger, J. Grimwood, K. Jabbari, A. Kuo, U. Maheswari, C. Martens, F.Maumus, R.P. Otillar, E. Rayko, A. Salamov, K. Vandepoele, B. Beszt eri, A. Gruber, M. Heijde, M.Katinka, T. Mock, K. Valentin, F. Verret, J.A. Berges, C. Brownlee, J.P. Cadoret, A. Chiovitti, C.J. Choi, S.Coesel, A. DeMartino, J.C. Detter, C. Durkin, A. Falciatore, J. Fournet, M. Haruta, M.J. Huysman, B.D.Jenkins, K. Jirout ova, R.E. Jorgensen, Y. Joubert, A. Kaplan, N. Kroger, P.G. Kroth, J. LaRoche, E.Lin dquist, M. Lommer, V. MartinJezequel, P.J. Lopez, S. Lucas, M. Mangogna, K. McGi nnis, L.K. Medlin, A. Montsant, M.P. Oudot-Le

Secq, C. Napoli, M. Obornik, M.S. Parker, J.L. Petit, B.M. Porcel, N. Poulsen, M. Ro bison, L. Rychlewski, T.A. Rynearson, J. Schmutz, H. Shapiro, M. Siaut, M. Stanley, M.R.Sussman, A.R. Taylor, A. Vardi, P. vonDassow, W. Vyverman, A. Willis, L.S. Wy rwicz, D.S. Rokhsar, J.Weissenbach, E.V. Armbrust, B.R. Green, Y. Van de Peer, I.V. Grigoriev

The Phaeodactylum genome reveals the evolutionary history of diatom genomes Nature, 456 (2008), pp. 239-244

10 F. Daboussi, S. Leduc, A. Marechal, G. Dubois, V. Guyot, C. PerezMichaut, A. Amato, A. Falciatore, A.Juillerat, M. Beurdeley, D.F. Voytas, L. Cavarec, P. Duchateau

Genome engineering empowers the diatom Phaeodactylum tricornutum for biotechnology

Nat. Commun., 5 (2014), p. 3831

11 V. De Riso, R. Raniello, F. Maumus, A. Rogato, C. Bowler, A. Falciatore Gene silencing in the marine diatom Phaeodactylum tricornutum Nucleic Acids Res., 37 (2009), Article e96

12.M. Siaut, M. Heijde, M. Mangogna, A. Montsant, S. Coesel, A. Allen, A. Manfredo nia, A. Falciatore, C.Bowler

Molecular toolbox for studying diatom biology in Phaeodactylum tricornutum Gene, 406 (2007), pp. 23-35

13 L.A. Zaslavskaia, J.C. Lippmeier, P.G. Kroth, A.R. Grossman, K.E. Apt Transformation of the diatom Phaeodactylum tricornutum (Bacillariophyceae) with a variety of selectable marker and reporter genes 
J. Phycol., 36 (2000), pp. 379-386

14 Q. Hu, M. Sommerfeld, E. Jarvis, M. Ghirardi, M. Posewitz, M. Seibert, A. Darzins Microalgal triacylglycerols as feedstocks for biofuel production: perspectives and advances

Plant J., 54 (2008), pp. 621-639

15.C. Caldana, Y. Li, A. Leisse, Y. Zhang, L. Bartholomaeus, A.R. Fernie, L. Willmitz er, P. Giavalisco

Systemic analysis of inducible target of rapamycin mutants reveal a general metabolic switch controlling growth in Arabidopsis thaliana

Plant J., 73 (2013), pp. 897-909

16 S. Imamura, Y. Kawase, I. Kobayashi, M. Shimojima, H. Ohta, K. Tanaka

TOR (target of rapamycin) is a key regulator of triacylglycerol accumulation in microalgae

Plant Signal. Behav., 11 (2016), Article e1149285

17.S. Imamura, Y. Kawase, I. Kobayashi, T. Sone, A. Era, S.Y. Miyagishima, M. Shi mojima, H. Ohta, K.Tanaka

Target of rapamycin (TOR) plays a critical role in triacylglycerol accumulation in microalgae

Plant Mol. Biol., 89 (2015), pp. 309-318

18 S. Mukaida, T. Ogawa, K. Ohishi, Y. Tanizawa, D. Ohta, M. Arita

The effect of rapamycin on biodiesel-producing protist Euglena gracilis

Biosci. Biotechnol. Biochem., 80 (2016), pp. 1223-1229

19 M. Laplante, D.M. Sabatini

mTOR signaling in growth control and disease

Cell, 149 (2012), pp. 274-293

20 T. Dobrenel, C. Caldana, J. Hanson, C. Robaglia, M. Vincentz, B. Veit, C. Meyer TOR signaling and nutrient sensing Annu. Rev. Plant Biol., 67 (2016), pp. 261-285

21 H. Yang, D.G. Rudge, J.D. Koos, B. Vaidialingam, H.J. Yang, N.P. Pavletich mTOR kinase structure, mechanism and regulation Nature, 497 (2013), pp. 217-223

22 .T.J. van Dam, F.J. Zwartkruis, J.L. Bos, B. Snel 
Evolution of the TOR pathway

J. Mol. Evol., 73 (2011), pp. 209-220

23.R. Loewith, E. Jacinto, S. Wullschleger, A. Lorberg, J.L. Crespo, D. Bonenfant, W. Oppliger, P. Jenoe, M.N. Hall

Two TOR complexes, only one of which is rapamycin sensitive, have distinct roles in cell growth control

Mol. Cell, 10 (2002), pp. 457-468

24 J.L. Crespo, M.N. Hall

Elucidating TOR signaling and rapamycin action: lessons from Saccharomyces cerevisiae

Microbiol. Mol. Biol. Rev., 66 (2002), pp. 579-591

25 M.H. Montane, B. Menand

ATP-competitive mTOR kinase inhibitors delay plant growth by triggering early differentiation of meristematic cells but no developmental patterning change

J. Exp. Bot., 64 (2013), pp. 4361-4374

26 J.L. Crespo, S. Diaz-Troya, F.J. Florencio

Inhibition of target of rapamycin signaling by rapamycin in the unicellular green alga Chlamydomonas reinhardtii

Plant Physiol., 139 (2005), pp. 1736-1749

27

B. Menand, T. Desnos, L. Nussaume, F. Berger, D. Bouchez, C. Meyer, C. Robaglia Expression and disruption of the Arabidopsis TOR (target of rapamycin) gene Proc. Natl. Acad. Sci. U. S. A., 99 (2002), pp. 6422-6427

28.C.M. Chresta, B.R. Davies, I. Hickson, T. Harding, S. Cosulich, S.E. Critchlow, J.P . Vincent, R. Ellston, D.Jones, P. Sini, D. James, Z. Howard, P. Dudley, G. Hughes, L . Smith, S. Maguire, M. Hummersone, K.Malagu, K. Menear, R. Jenkins, M. Jacobse n, G.C. Smith, S. Guichard, M. Pass

AZD8055 is a potent, selective, and orally bioavailable ATP-competitive mammalian target of rapamycin kinase inhibitor with in vitro and in vivo antitumor activity Cancer Res., 70 (2010), pp. 288-298

29 R.R. Guillard, J.H. Ryther

Studies of marine planktonic diatoms. I. Cyclotella nana Hustedt, and Detonula confervacea(cleve) Gran

Can. J. Microbiol., 8 (1962), pp. 229-239 
30.J. Rumin, H. Bonnefond, B. SaintJean, C. Rouxel, A. Sciandra, O. Bernard, J.P. C adoret, G. Bougaran

The use of fluorescent Nile red and BODIPY for lipid measurement in microalgae

Biotechnol. Biofuels, 8 (2015), p. 42

31 W. Chen, C. Zhang, L. Song, M. Sommerfeld, Q. Hu

A high throughput Nile red method for quantitative measurement of neutral lipids in microalgae

J. Microbiol. Methods, 77 (2009)

32 J. Vives-Rego, P. Lebaron, G. Nebe-von Caron

Current and future applications of flow cytometry in aquatic microbiology

FEMS Microbiol. Rev., 24 (2000), pp. 429-448

\section{$33 \mathrm{~J}$. Monod}

The growth of bacterial cultures

Annu. Rev. Microbiol., 3 (1949), pp. 371-394

34.C. Cagnon, B. Mirabella, H.M. Nguyen, A. Beyly-

Adriano, S. Bouvet, S. Cuiné, F. Beisson, G. Peltier, Y.Li-Beisson

Development of a forward genetic screen to isolate oil mutants in the green microalga Chlamydomonas reinhardtii

Biotechnol. Biofuels, 6 (2013), pp. 1-12

35.J.-F. Cavalier, D. Lafont, P. Boullanger, D. Houisse, J. Giallo, J.-

M. Ballester, F. Carrière

Validation of lipolysis product extraction from aqueous/biological samples, separation and quantification by thin-layer chromatography with flame ionization detection analysis using O-cholesteryl ethylene glycol as a new internal standard J. Chromatogr. A, 1216 (2009), pp. 6543-6548

36.Y.B. Ali, F. Carriere, R. Verger, S. Petry, G. Muller, A. Abousalham

Continuous monitoring of cholesterol oleate hydrolysis by hormone-sensitive lipase and other cholesterol esterases

J. Lipid Res., 46 (2005), pp. 994-1000

37 N. Hempel, I. Petrick, F. Behrendt

Biomass productivity and productivity of fatty acids and amino acids of microalgae strains as key characteristics of suitability for biodiesel production

J. Appl. Phycol., 24 (2012), pp. 1407-1418

38 M.M. Bradford 
A rapid and sensitive method for the quantitation of microgram quantities of protein utilizing the principle of protein-dye binding

Anal. Biochem., 72 (1976), pp. 248-254

39 M. Haissaguerre, N. Saucisse, D. Cota

Influence of mTOR in energy and metabolic homeostasis

Mol. Cell. Endocrinol., 397 (2014), pp. 67-77

40 M. Laplante, D.M. Sabatini

An emerging role of mTOR in lipid biosynthesis

Curr. Biol., 19 (2009), pp. R1046-1052

41 L.F. Wentzinger, T.J. Bach, M.A. Hartmann

Inhibition of squalene synthase and squalene epoxidase in tobacco cells triggers an up-regulation of 3-hydroxy-3-methylglutaryl coenzyme a reductase

Plant Physiol., 130 (2002), pp. 334-346

42.M. Fabris, M. Matthijs, S. Carbonelle, T. Moses, J. Pollier, R. Dasseville, G.J. Baar t, W. Vyverman, A.Goossens

Tracking the sterol biosynthesis pathway of the diatom Phaeodactylum tricornutum New Phytol., 204 (2014), pp. 521-535

43

M.T. Ta, T.S. Kapterian, W. Fei, X. Du, A.J. Brown, I.W. Dawes, H. YangAccumulatio $\mathrm{n}$ of squalene is associated with the clustering of lipid droplets

FEBS J., 279 (2012), pp. 4231-4244

44 Y. Lu, W. Zhou, L. Wei, J. Li, J. Jia, F. Li, S.M. Smith, J. Xu

Regulation of the cholesterol biosynthetic pathway and its integration with fatty acid biosynthesis in the oleaginous microalga Nannochloropsis oceanica

Biotechnol. Biofuels, 7 (2014), p. 81

45 S.W. Rampen, B.A. Abbas, S. Schouten, J.S. Sinninghe Damste

A comprehensive study of sterols in marine diatoms (Bacillariophyta): implications for their use as tracers for diatom productivity

Limnol. Oceanogr., 55 (2010), pp. 91-105

46 P. Dong, F. Xiong, Y. Que, K. Wang, L. Yu, Z. Li, M. Ren

Expression profiling and functional analysis reveals that TOR is a key player in regulating photosynthesis and phytohormone signaling pathways in Arabidopsis Front. Plant Sci., 6 (2015), p. 677 
47.J.B. Madeira, C.A. Masuda, C.M. Maya-Monteiro, G.S. Matos, M. MonteroLomeli, B.L. Bozaquel-Morais

TORC1 inhibition induces lipid droplet replenishment in yeast

Mol. Cell. Biol., 35 (2015), pp. 737-746

48 S. Imamura, A. Ishiwata, S. Watanabe, H. Yoshikawa, K. Tanaka

Expression of budding yeast FKBP12 confers rapamycin susceptibility to the unicellular red alga Cyanidioschyzon merolae

Biochem. Biophys. Res. Commun., 439 (2013), pp. 264-269

49 P. Singh, S. Kumari, A. Guldhe, R. Misra, I. Rawat, F. Bux

Trends and novel strategies for enhancing lipid accumulation and quality in microalgae Renew. Sust. Energ. Rev., 55 (2016), pp. 1-16

50 S. Wu, A. Huang, B. Zhang, L. Huan, P. Zhao, A. Lin, G. Wang

Enzyme activity highlights the importance of the oxidative pentose phosphate pathway in lipid accumulation and growth of Phaeodactylum tricornutum under $\mathrm{CO}_{2}$ concentration

Biotechnol. Biofuels, 8 (2015), p. 78

51 L. Alipanah, J. Rohloff, P. Winge, A.M. Bones, T. Brembu

Whole-cell response to nitrogen deprivation in the diatom Phaeodactylum tricornutum J. Exp. Bot., 66 (2015), pp. 6281-6296

52 M. Matthijs, M. Fabris, S. Broos, W. Vyverman, A. Goossens

Profiling of the early nitrogen stress response in the diatom Phaeodactylum tricornutum reveals a novel family of RING-domain transcription factors

Plant Physiol., 170 (2016), pp. 489-498

53. A.Mühlroth, K. Li, G. Røkke, P. Winge, Y. Olsen, M.F. Hohmann Marriott, O. Vadstein, A.M. Bones

Pathways of lipid metabolism in marine algae, co-expression network, bottlenecks and candidate genes for enhanced Production of EPA and DHA in species of chromista Mar. Drugs, 11 (2013), pp. 4662-4697

54 A.L. Edinger, C.M. Linardic, G.G. Chiang, C.B. Thompson, R.T. Abraham

Differential effects of rapamycin on mammalian target of rapamycin signaling functions in mammalian cells

Cancer Res., 63 (2003), pp. 8451-8460

55 J.S. Hardwick, F.G. Kuruvilla, J.K. Tong, A.F. Shamji, S.L. Schreiber

Rapamycin-modulated transcription defines the subset of nutrient-sensitive signaling pathways directly controlled by the Tor proteins 
Proc. Natl. Acad. Sci. U. S. A., 96 (1999), pp. 14866-14870

56.Q. Sun, X. Chen, J. Ma, H. Peng, F. Wang, X. Zha, Y. Wang, Y. Jing, H. Yang, R. Chen, L. Chang, Y.Zhang, J. Goto, H. Onda, T. Chen, M.R. Wang, Y. Lu, H. You, D. Kwiatkowski, H. Zhang

Mammalian target of rapamycin up-regulation of pyruvate kinase isoenzyme type M2 is critical for aerobic glycolysis and tumor growth

Proc. Natl. Acad. Sci. U. S. A., 108 (2011), pp. 4129-4134

57 R. Loewith, M.N. Hall

Target of rapamycin (TOR) in nutrient signaling and growth control

Genetics, 189 (2011), pp. 1177-1201

58 A. Shemi, S. Ben-Dor, A. Vardi

Elucidating the composition and conservation of the autophagy pathway in photosynthetic eukaryotes

Autophagy, 11 (2015), pp. 701-715 